$\S=-1$ 圆

\title{
Learning Style Preferences Among Degree Students in Academic English Course in UTHM
}

\author{
Thuwaibah Mohd Junaid ${ }^{1}$, Nadia Nur Afiqah Ismail ${ }^{2}$ \\ ${ }^{1,2}$ Department of English Language and Linguistic, Centre for Language Studies, University Tun Hussein Onn Malaysia, Malaysia. \\ *Corresponding author E-mail: thuwaibah@uthm.edu.my
}

\begin{abstract}
This study was conducted to identify the major learning style preference among UTHM degree students semester 2 2015/2016 in Academic English classroom as well as to identify the differences between the learning style preferences of male and female students. A total of 150students from eight different faculties comprised of 75 male and 75 female students were involved in this study. The Perceptual Learning Style Preferences Questionnaire (PLSPQ) which was developed by Reid (1987) has been used as the instrument of the study. The findings revealed that the major learning style preference of the students was Kinesthetic learning style. Moreover, the findings also revealed that there were no significance differences at $\alpha=0.05$ between the learning styles preference of male and female UTHM degree students' semester 2 2015/2016 in Academic English classroom.
\end{abstract}

Keywords: ESL, gender, Perceptual Learning Style Preference Questionnaire (PLSPQ); learning style Keywords: ESL; gender; Perceptual Learning Style Preference Questionnaire (PLSPQ); learning style

\section{Introduction}

Learners learning styles are the most important factors in determining how well they learn second language. Reid defines learning styles as internally based characteristics often not perceived or consciously used by learners for the intake and comprehension of new information(1). Every student has their own way of perceiving, analyzing, processing information, as well as applying the information in his learning processes. It is important to know the learning styles preferences of the students because it could affect the learners' way of receiving, processing as well as understanding the information in the lesson. Moreover, it may also affect the learners' attitude to learn the language.

According to Ibrahim and Ramli, knowing self-learning preferences will help students to plan their learning especially language learning in order to make their learning more meaningful and effective(2). Furthermore, learning style will also affect how students act in group, participate in classroom activities, relate to others, solve problems, and as well as learn the language.

In Malaysian educational school system, our students have been exposed to English language as their second language starting from the kindergarten, primary school until secondary school. There are usually five periods of English in a week, totaling up to 200 minutes or roughly three and a half hours (3). In UTHM, English course is a prerequisite course and it is compulsory for every students. Degree students will be exposed to three different subjects in three different semesters which are Academic English (UWB 10102), Effective Communication (UWB 10202) and Technical Writing (UWB 20302). However, there are some students who still cannot speak English fluently even though they have been learning English for more than 11 years during their school years starting from kindergarten until secondary school.
Some students show that they have lack of confidence to use the language.

English is spoken and used as a second language (L2) in the countries which were typically ex-colonies of the United Kingdom or the United States including Malaysia, India, Philippines and Nigeria (4). In Malaysian educational school system, our students have been exposed to English language as their second language starting from the kindergarten, primary school until secondary school. In UTHM, English course is a prerequisite course and it is compulsory for every students. Degree students will be exposed to three different subjects in four different semesters which are Foundation English (UWB 10100), Academic English (UWB 10102), Effective Communication (UWB 10202) and Technical Writing (UWB 20302). However, there are some students who still cannot speak English fluently even though they have been learn English for more than 11 years during their school years starting from kindergarten until secondary school. Some students show that they have lack of confidents to use the language.

One of the questions posted by researcher in second language learning is why there are some students could learn successfully but some of them fail to learn and is there a match or mismatch between students' learning styles preferences and teacher's teaching style. To address these issues, the most important things that teachers need to know are their students' learning style preferences in learning English as well as the factors that contributed to the different learning style preferences among the students.

Sometimes, second language teachers as well as learners do not seem to realize the importance of taking into considerations the learners' learning styles and preferences in planning and designing for the activities and approaches to be used during the lesson conducted in the classroom. The serious mismatch between the teachers teaching styles with learners learning styles and preferences will demotivate the students from giving full cooperation as well as participating during the lesson. Mohamed Ismail and Yusuf stated that: 
"This mismatch may have negative effects in mastering content or language skills. It is therefore, necessary that the students understand their own learning styles so that they can derive optimum benefits from their learning. It is also necessary for teachers to understand the learning styles of the students so that they can adjust their own teaching style to match those of the students"(5).

Moreover, the implementation of new technologies with the used of gadgets by students nowadays also contribute to this issue. Technology is continuously altering the students' relationship to information and changing the way students learn. Thus, lessons that employ the 'one-size-fits-all' approach of teaching and learning no longer seem to be practical. With the evolvement of technological learning environment, the 21 st century learners would have diverse requirements and preferences from their learning environment. They would have a particular learning preferences and styles due to their upbringing background and technological experiences (6).

Some approaches and activities conducted in the classroom may work with some students but they may be difficult with other students especially students with lower level of proficiency. The more a teacher knows about factors that influenced the learners' learning styles preferences, the more readily the teachers can come to grips with the nature of individual differences in the classroom It is important to be aware of the feature of learning style preference among learners and to respond flexibly by employing a broad range of teaching strategies to better reach students of different learning preferences (7).

It is very important for a teacher to determine their students learning styles as well as to accommodate different learning styles in the classroom. Many researchers have done research regarding the learning style preferences; however in UTHM there are still lacks of information regarding this issue especially for English subject Hence, it is important to conduct this type of research so that it could help the teachers to improve their teaching styles and it could also help the students to improve their level of English language.

Knowing about the factors that could contribute to the differences of their students' learning style preferences, problems that may occur due to the mismatch between students' learning styles preferences and teacher's teaching style and its impact towards the level of interest, level of confident, as well as motivation will help teacher to be aware of taking into considerations regarding students' learning styles preferences before they choose the appropriate activities for their lesson. Sometimes, teacher may not be aware of their own teaching styles and that their teaching style preferences may be differ from their students learning style preferences.

A good teacher needs to put in mind that students learn differently between one another and there are many factors that play crucial roles in learning style preferences of their students. So, teachers need to play their responsibility to apply different types of teaching styles to suite with the students' abilities. So, the purpose of this research study was to identify major learning style preference among UTHM degree students, to identify the major learning style preference among UTHM degree students semester 2 2015/2016 in Academic English classroomand to identify the differences between the learning styles preference of male and female UTHM degree students semester 2 2015/2016 in Academic English classroom.

This study may be significant to curriculum designers, language teachers and lecturers as well as students. It is hoped that this study will help the curriculum designers, language teachers and lecturers to design and produce academic materials that suit with the students learning styles. It is also expected that teachers and lecturers can use the information from the findings as their guidelines in order to prepare interesting lessons, create creative teaching aids as well to create situation or environment where students feel motivated to learn the English subject. In addition, it is hoped that the findings of this study will allow the students to recognize their areas of strength and weaknesses in learning English as a second language. Furthermore, students may also learn how to deal with their problems in learning English.

This study is limited to only UTHM degree students' semester 2 2015/2016. Moreover, this study focuses only in Academic English classroom. Therefore, the findings cannot be generalized to the students in different subjects and students from other university.

\section{Experimental Details}

The research design of this study is quantitative research. The purposes of this study as indicated earlier were to identify the major learning style preference among UTHM degree students semester 2 2015/2016 in Academic English classroom as well as to identify the differences between the learning style preferences of male and female students. The findings of this study will be based on quantitative analysis.

The samples of this study were randomly chosen, comprised of 150 students. There were equal number of both gender which were 75 male students and 75 female students. There were from eight different faculties in UTHM which are Faculty of Civil and Environmental Engineering (FKAAS), Faculty of Electrical and Electronic Engineering (FKEE), Faculty of Mechanical and Manufacturing Engineering (FKMP), Faculty of Technology Management and Business (FPTP), Faculty of Technical and Vocational Education (FPTV), Faculty of Computer Science and Information Technology (FSKTM), Faculty of Science, Technology and Human Development (FSTPI), and Faculty of Technical Engineering (FTK)

The instrument that has been chosen to identify the perceptual learning style among UTHM degree students semester 2 2015/2016 in Academic English classroom was the Perceptual Learning Style Preferences Questionnaire (PLSPQ) by Reid (1). The perceptual learning style preference includes in this questionnaire are visual, auditory, tactile, kinesthetic, group, and individual. This set of questionnaires comprises of two sections which are Section A and Section B. This instrument is used to congregate the descriptive information from the samples.

Section A elicited the demographic data on the sample's background. The information gathered was on age, gender, faculty as well as race.

Section B comprises of 30 items regarding perceptual learning style preference. The PLSPQ is an instrument which measures six learning style preferences: visual, auditory, kinesthetic, tactile, group and individual learning. Each of these six learning style preferences is examined through five statements. All of the 30 questionnaires are randomly arranged. For example, the first statement is: "When the teacher tells me the instructions I understand better" is for auditory learning style. The second statement is: "I prefer to learn by doing something in class" is for Kinesthetic learning style. Table 3.3.1 represents the grouping of the PLSPQ's statements according to their learning styles. The learning style preferences are measured on the 5-point Likert scale ranging from 'strongly agree', 'agree', 'undecided', 'disagree' and 'strongly disagree'. (See Table 3.3.2)

Table 2.1: The grouping of the PLSPQ's Statements according to their Learning Styles Categories

\begin{tabular}{|l|l|l|}
\hline $\begin{array}{l}\text { Learning } \\
\text { Style Cate- } \\
\text { gory }\end{array}$ & $\begin{array}{l}\text { Number of } \\
\text { the State- } \\
\text { ment }\end{array}$ & The Statement \\
\hline Visual & 6 & $\begin{array}{l}\text { I learn better by reading what the teacher } \\
\text { writes on the chalkboard. }\end{array}$ \\
\hline & 10 & $\begin{array}{l}\text { When I read instructions, I remember } \\
\text { them better. }\end{array}$ \\
\hline & 12 & $\begin{array}{l}\text { I understand better when I read instruc- } \\
\text { tions. }\end{array}$ \\
\hline & 24 & $\begin{array}{l}\text { I learn better by reading than by listen- } \\
\text { ing to someone. }\end{array}$ \\
\hline & 29 & I learn more by reading textbooks than \\
\hline
\end{tabular}




\begin{tabular}{|c|c|c|}
\hline & & by listening to lectures. \\
\hline \multirow[t]{5}{*}{ Auditory } & 1 & $\begin{array}{l}\text { When the teacher tells me the instruc- } \\
\text { tions I understand better. }\end{array}$ \\
\hline & 7 & $\begin{array}{l}\text { When someone tells me how to do } \\
\text { something in class, I learn it better. }\end{array}$ \\
\hline & 9 & $\begin{array}{l}\text { I remember things I have heard in class } \\
\text { better than things I have read. }\end{array}$ \\
\hline & 17 & $\begin{array}{l}\text { I learn better in class when the teacher } \\
\text { gives a lecture. }\end{array}$ \\
\hline & 20 & $\begin{array}{l}\text { I learn better in class when I listen to } \\
\text { someone. }\end{array}$ \\
\hline \multirow[t]{5}{*}{ Kinesthetic } & 2 & $\begin{array}{l}\text { I prefer to learn by doing something in } \\
\text { class. }\end{array}$ \\
\hline & 8 & When I do things in class, I learn better. \\
\hline & 15 & $\begin{array}{l}\text { I enjoy learning in class by doing exper- } \\
\text { iments. }\end{array}$ \\
\hline & 19 & $\begin{array}{l}\text { I understand things better in class when I } \\
\text { participate in role-playing. }\end{array}$ \\
\hline & 26 & $\begin{array}{l}\text { I learn best in class when I can partici- } \\
\text { pate in related activities. }\end{array}$ \\
\hline \multirow[t]{5}{*}{ Tactile } & 11 & $\begin{array}{l}\text { I learn more when I can make a model of } \\
\text { something. }\end{array}$ \\
\hline & 14 & $\begin{array}{l}\text { I learn more when I make something for } \\
\text { a class project. }\end{array}$ \\
\hline & 16 & $\begin{array}{l}\text { I learn better when I make drawings as I } \\
\text { study. }\end{array}$ \\
\hline & 22 & $\begin{array}{l}\text { When I build something, I remember } \\
\text { what I have learned better. }\end{array}$ \\
\hline & 25 & $\begin{array}{l}\text { I enjoy making something for a class } \\
\text { project. }\end{array}$ \\
\hline \multirow[t]{5}{*}{ Group } & 3 & $\begin{array}{l}\text { I get more work done when I work with } \\
\text { others. }\end{array}$ \\
\hline & 4 & I learn more when I study with a group. \\
\hline & 5 & $\begin{array}{l}\text { In class, I learn best when I work with } \\
\text { others. }\end{array}$ \\
\hline & 21 & $\begin{array}{l}\text { I enjoy working on an assignment with } \\
\text { two or three classmates. }\end{array}$ \\
\hline & 23 & I prefer to study with others. \\
\hline \multirow[t]{5}{*}{ Individual } & 13 & $\begin{array}{l}\text { When I study alone, I remember things } \\
\text { better. }\end{array}$ \\
\hline & 18 & When I work alone, I learn better. \\
\hline & 27 & $\begin{array}{l}\text { In class, I work better when I work } \\
\text { alone. }\end{array}$ \\
\hline & 28 & I prefer working on projects by myself. \\
\hline & 30 & I prefer to work by myself. \\
\hline
\end{tabular}

Table 2.2: Likert-type Scale for the Questionnaire

\begin{tabular}{|l|l|}
\hline Item & \multicolumn{1}{|c|}{ Response } \\
\hline 1 & Strongly Agree \\
2 & Agree \\
3 & Undecided \\
4 & Disagree \\
5 & Strongly Disagree \\
\hline
\end{tabular}

The PLSPQ has a self-scoring sheet. The questions are grouped into six sets. The first set is for visual learning style consists of statements number $6,10,12,24$, and 29 . The second set is for tactile learning style consists of statements number 11, 14, 16, 22, and 25 . The third set is for auditory learning style consists of statements number $1,7,9,17$, and 20 . The fourth set is for group learning style consists of statements number 3, 4, 5, 21, and 23 . The fifth set is for kinesthetic learning style consists of statements number $2,8,15,19$, and 26 . The last set is for individual learning style consists of statements number $13,18,27,28$, and 30 . Table 3.3.3 represents the items for each subscale.

Table 2.3: Items for Each Subscale

\begin{tabular}{|l|l|}
\hline Subscale & Items \\
\hline Visual & $6,10,12,24,29$ \\
Auditory & $1,7,9,17,20$ \\
Kinesthetic & $2,8,15,19,26$ \\
Tactile & $11,14,16,22,25$ \\
Group & $3,4,5,21,23$ \\
Individual & $13,18,27,28,30$ \\
\hline
\end{tabular}

The PLSPQ has been adopted and printed in a booklet form. An introductory paragraph regarding the current study has been added in the first page. Then, questions regarding the student's demographic background have been added in the second page (See Appendix A) such as age, gender, faculty as well as race. Next, the instructions as presented in the original PLSPQ, has been provided in the third page. The 30 statements of the PLSPQ have been provided in page 3 until page 4 .

The survey was conducted in UTHM. At the initial stage in obtaining the data for the research, the researchers seek for the permission by the lecturers who were involved in Academic English classroom Semester $22015 / 2016$ to have their students as the respondents for this study. Then, the questionnaires were distributed to the respondents. They were also informed about the purpose of the research.

The data has been analyzed using two ways. First, each questionnaire has been analyzed using the self-scoring sheet that has been provided in the original PLSPQ to determine the learning style preferences.

The marks for each questions of learning style were given based on the numerical value for each subscale presented in the original PLSPQ. (See Table 2.4) Then, the total marks for each category are multiply by 2 . The marks that have been multiply by 2 will determine the learning style preference of the students by referring to the score scale presented in the original PLSPQ. (See Table 2.5)

Table 2.4: Numerical Value for Each Subscale

\begin{tabular}{|c|c|c|c|c|}
\hline $\begin{array}{c}\text { SA } \\
\text { Strongly } \\
\text { Agree }\end{array}$ & $\begin{array}{c}\text { A } \\
\text { Agree }\end{array}$ & $\begin{array}{c}\text { Undecided } \\
\text { Und }\end{array}$ & $\begin{array}{c}\text { D } \\
\text { Disagree }\end{array}$ & $\begin{array}{c}\text { SD } \\
\text { Strongly } \\
\text { Disagree }\end{array}$ \\
\hline 1 & 2 & 3 & 4 & 5 \\
\hline
\end{tabular}

Table 2.5: The Interpretations of the Score Scales of the PLSPQ

\begin{tabular}{|l|l|}
\hline Major learning style preference & Score: $38-50$ \\
\hline Minor learning style preference & Score: $25-37$ \\
\hline Negligible learning style preference & Score: $0-24$ \\
\hline
\end{tabular}

Secondly, based from the finding from the questionnaires, the data is analyzed quantitatively using Statistical Package for the Social Sciences (SPSS) version 18.0. The data gathered using the SPSS is analyzed in relation to the purpose of the study. The means of the students' learning style preferences were measured in SPSS for the whole sample and then subdivided for each gender in order to allow comparison between the groups (Alsafi, W.A., 2010). In fact, the means had been chosen because they have been used in the original study by Reid (1). Furthermore, the percentages and frequencies of the responses regarding the learning style preferences were calculated in the form of tables.

\section{Results and Discussion}

The students' demographic background is presented in this section. The demographic background comprises of gender (Table 3.1).

Table 3.1: Respondents' Gender

\begin{tabular}{|l|l|r|r|r|r|}
\hline \multirow{2}{*}{} & F & Percent & \multicolumn{1}{c|}{$\begin{array}{c}\text { Valid Per- } \\
\text { cent }\end{array}$} & $\begin{array}{c}\text { Cumulative } \\
\text { Percent }\end{array}$ \\
\hline \multirow{3}{*}{ Valid } & Male & 75 & 50.0 & 50.0 & 50.0 \\
\cline { 2 - 6 } & Female & 75 & 50.0 & 50.0 & 100.0 \\
\cline { 2 - 6 } & Total & 150 & 100.0 & 100.0 & \\
\hline
\end{tabular}

Out of the total sample of 150 students, 75 are male students and other 75 are female students.

Research Question 1: What is the major learning style preference among UTHM degree students semester 2 2015/2016 in Academic English classroom?

The major learning style preference among UTHM degree students semester 2 2015/2016 in Academic English classroom is presented by using Students' percentage (Figure 1). 


\section{Perceptual Learning Style Preferences}

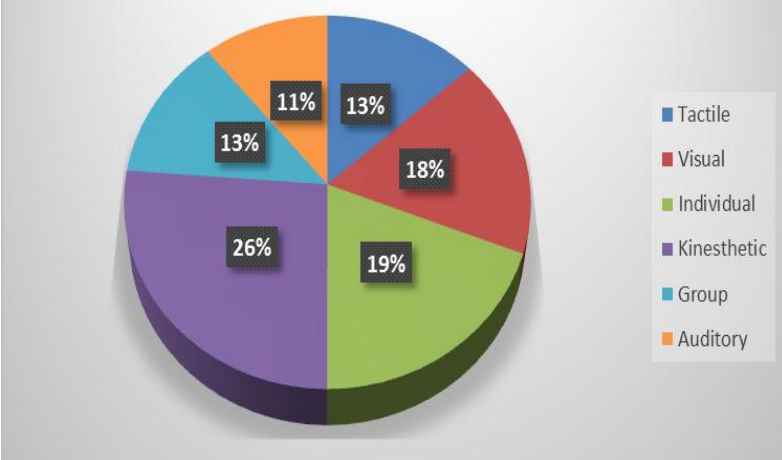

Fig. 1: Students' Percentage towards Perceptual Learning Style Preferences

Overall, the results from the study reveal that UTHM degree students' semester 2 2015/2016 had major preference towards Kinesthetic learning style (26\%). Individual learning style recorded as the second highest preference with the percentage of $19 \%$ followed by Visual as the third highest percentage which is $18 \%$. Group and tactile scored the same percentage which is $13 \%$ and the least percentage scored by Auditory which is $11 \%$.

Research Question 2: Is there a difference between the learning styles preference of male and female UTHM degree students' semester 2 2015/2016 in Academic English classroom?

\begin{tabular}{|l|l|l|l|l|l|l|}
\hline Gender & N & Mean & SD & Df & t & Sig. \\
\hline Male & 75 & 26.69 & 8.671 & 148 & 0.859 & 0.392 \\
\hline Female & 75 & 25.57 & 7.228 & & & \\
\hline
\end{tabular}

The study indicates that there was no significance difference at $\alpha=$ 0.05 between the learning styles preference of male and female UTHM degree students' semester 2 2015/2016 in Academic English classroom since the computed T-test value was only 0.859 . Different students will have different learning styles especially in learning second language. It is a big challenge for every student to learn and acquire second language. According to Mulalic, Shah, and Ahmad, learning language is among the most challenging lifelong pursuits one has to undertake(8). Therefore, the personal reflections on how one acquires language, could serve as a key to an academic mastering of the native tongue, and the learning of the second language. By looking at the importance of determining learning style of the students, this study has been conducted in order to investigate the major learning style preferences as well as the learning style differences between UTHM male and female degree students semester 2 2015/2016 in Academic English classroom. These two research objectives have been achieved through the use of PLSPQ.

As all students learn in different ways, what works well for one learner may not be useful or favorable for another (9). Moreover, Reid suggested that although stylistic preferences are relatively stable, students need to be adaptable, since research show that the ability of students to employ multiple learning styles results in greater classroom success(1).

Based on this quantitative study, it shows that UTHM degree students' semester 2 2015/2016 had major preference towards kinesthetic learning style in Academic English classroom with the mean of $26.13 \%$ (SD of 7.975). As observed, the result of this present study is consistent with the Reid's study. Moreover, the finding is also supported by the study of Mulalic, Parilah\&Fauziah. Based on the study, result revealed that the dominant learning style of UNITEN students in ESL classroom was Kinesthetic.

It can be stated that UTHM degree students' semester 2 2015/2016 learn best in active "hands-on" approach. Working with the materials gives them the most successful learning situation. According to Sauvola (2010) learners who feel uncomfortable sitting in one place for a long period of time may have a kinesthetic learning style preference, that is, they learn through movement. This can be the most challenging learning style to incorporate in language teaching as there often is not enough time or even physical space in the classroom to move around. However, exercises such as roleplays, games and dramas may help kinesthetic learners. Moreover, Reid reports that non-native learners tend to prefer learning style through physical involvement(1). Kinesthetic learning style could really help the students to practice their English among their friends especially when they collaborate with each other during the physical activities.

Independent-Samples T-test has been used to determine the significant differences $\alpha=0.05$ between the learning style preferences of male and female UTHM degree students' semester 2 2015/2016 in Academic English classroom. According to Ramayah, Sivanandan, Nasrijal, Letchumanan, and Leong, T-test is highly suitable for a bivariate analysis involving a discrete variable of two groups (male and female) and a continuous variable (Visual, Tactile, Auditory, Kinesthetic, Group and Individual)(10). Based on the findings, it is found that there were no significant differences at $\alpha=$ 0.05 between the learning styles preference of male and female UTHM degree students' semester 2 2015/2016 in Academic English classroom. The findings collaborate with the findings of Wang's which cited that there was no significant differences $\alpha=$ 0.05 in the learning style preferences due to gender (7).

However, the results differs from the earlier findings by Mulalic, Shah and Ahmad's who found that there were significant different in learning style between male and female students regarding $\mathrm{Au}$ ditory and Kinesthetic learning style(8). Furthermore, the findings contrast with previous research by Reid's who indicated that male students preferred Visual and Tactile learning style more significantly than female students(1). The findings may be different due to the several reasons. First, the sample of the study may be the reason that contributed to the differences of the findings in the present study. Different students may have different level of English proficiency and their level of confident towards English language may also be different. Therefore both genders were struggling to acquire the English as second language using different types of learning styles. Second, the subject or the syllabus was also different between the previous studies and the present study. Although they were classified under English classroom, but the design of each English subject and syllabus might be different. According to Reid learning styles among learners varied according to the subjects studied, length of residence, age, and levels of proficiency in the language(1).

\section{Conclusion}

Generally, the study answered the two research questions that have been stated in the early chapter. The present study revealed that based on this quantitative, it shows that UTHM degree students' semester 2 2015/2016 had major preference towards kinesthetic learning style in Academic English classroom. Moreover, there were no significant differences at $\alpha=0.05$ between the learning styles preference of male and female UTHM degree students' semester 2 2015/2016 in Academic English classroom.

\section{Acknowledgment}

This research is a paper under the Short Term Grant (STG) with the vote number of U137 by Research, Innovation, Commercialization, Consultancy Office(ORICC) of Universiti Tun Hussein Onn Malaysia (UTHM). We would like to thank everybody involved for the success of this research and grant. Thank you. 


\section{References}

[1] Reid JM. The learning style preferences of ESL students. TESOL quarterly. 1987;21(1):87-111.

[2] Ramli N, Ibrahim NM. A Comparative Study On the Learning Styles of Second Year Education (Living Skills) Students and the Teaching Styles of Their Lecture. This Project Report is Prepared as a Requirement for The Bestowal of Bachelor of Science and Education (TESL) Faculty of Educational Universiti Teknologi Malaysia30 th APRIL; 2008.

[3] Murugesan V. Malaysia promotes excellence in English. ESL magazine. 2003;6(2):26-8.

[4] Thirusanku J, Yunus MM. Status of English in Malaysia. Asian Social Science. 2014;10(14):254.

[5] Ismail M, Ismail Y. Exploring English language learning styles of Malay students at the International Islamic University Malaysia. World Applied Sciences Journal. 2012;20(8):1072-81.

[6] Bennett S, Maton K, Kervin L. The 'digital natives' debate: A critical review of the evidence. British journal of educational technology. 2008;39(5):775-86.

[7] Wang Q. The national curriculum changes and their effects on English language teaching in the People's Republic of China. International handbook of English language teaching. 2007:87-105.

[8] Ahmad F. Learning-style preference of ESL students. Asean Journal of Teaching and Learning in Higher Education (AJTLHE). 2009;1(2):9-17.

[9] Chu M-p, Nakamura T. A study of Chinese and Japanese college students' L2 learning styles. Asian Culture and History. 2010;2(2):30.

[10] Ramayah M, Sivanandan P, Nasrijal NH, Letchumanan T, Leong LC. Preferred learning style: Gender influence on preferred learning style among business students. Journal of US-China Public Administration. 2009;6(4):65-78. 